\title{
Whole Genome Sequences of the Raspberry and Strawberry Pathogens Phytophthora rubi and P. fragariae
}

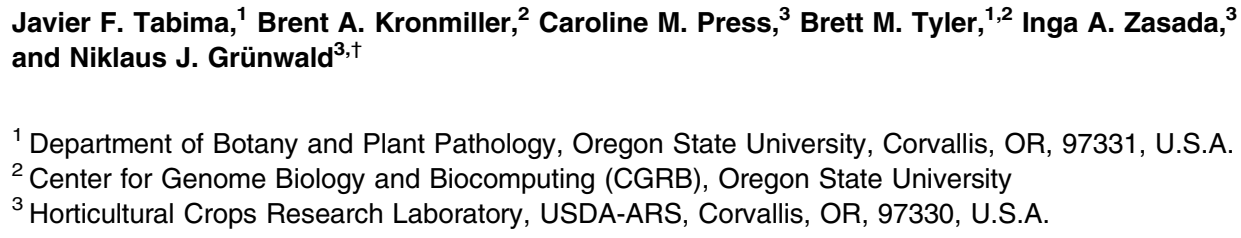

Javier F. Tabima, ${ }^{1}$ Brent A. Kronmiller, ${ }^{2}$ Caroline M. Press, ${ }^{3}$ Brett M. Tyler,,${ }^{1,2}$ Inga A. Zasada, and Niklaus J. Grünwald ${ }^{3, \dagger}$

${ }^{1}$ Department of Botany and Plant Pathology, Oregon State University, Corvallis, OR, 97331, U.S.A.

${ }^{2}$ Center for Genome Biology and Biocomputing (CGRB), Oregon State University

${ }^{3}$ Horticultural Crops Research Laboratory, USDA-ARS, Corvallis, OR, 97330, U.S.A.

\begin{abstract}
Phytophthora rubi and $P$. fragariae are two closely related oomycete plant pathogens that exhibit strong morphological and physiological similarities but are specialized to infect different hosts of economic importance, namely, raspberry and strawberry. Here, we report the draft genome sequences of these two Phytophthora species as a first step toward understanding the genomic processes underlying plant host adaptation in these pathogens.
\end{abstract}

\section{Genome Announcement}

More than 150 species of oomycete plant pathogens are harbored in the genus Phytophthora (Erwin and Ribeiro 1996; Kamoun et al. 2015). These organisms are highly diverse in lifestyle, host preference, and economic importance (Kamoun et al. 2015). Whole-genome sequences of various species in the genus Phytophthora have recently been published, yielding novel insights into the molecular basis of plant disease, such as the identification of effector proteins that can disrupt the physiology of the host (Haas et al. 2009; Tyler et al. 2006). Here, we present the whole-genome sequences of two soil-borne Phytophthora sister species, $P$. fragariae and $P$. rubi. These are highly similar in morphology and physiology but infect different hosts. Sequencing the genomes of these species will advance our understanding of the genomic mechanisms underlying host adaptation and knowledge of molecular mechanisms of plant pathogenicity (Stewart et al. 2014).

Genomic DNA was extracted from P. rubi 'pd0101050015038' (isolated in The Netherlands by K. Rosendhal from red raspberry) and $P$. fragariae CBS 209.46 (isolated in England by C. J. Hickman from strawberry). Genomes were sequenced by the Beijing Genomics Institute (BGl, Beijing), using the Illumina HiSeq2000 platform (Illumina, San Diego, CA, U.S.A.), using TruSeq libraries (paired end reads, insert size of $500 \mathrm{bp}$, average read length of $90 \mathrm{bp}$ ). Assemblies were performed using SOAPdenovo2 (kmer size of 36) (Luo et al. 2012). Transcriptomes of both species were also sequenced by BGI, using the Illumina HiSeq2000 technology (paired end reads, insert size of $500 \mathrm{bp}$, average read length of $90 \mathrm{bp}$ ). To obtain high-quality gene calls, the transcriptomes were assembled using Trinity (using nonstrand specific parameters, $100 \mathrm{~Gb}$ of RAM, and $10 \mathrm{CPU}$ cores) (Grabherr et al. 2011) and were translated into amino-acid sequences using TransDecoder (Haas et al. 2013). To generate a reference database, gene prediction and annotation for the nuclear genomes of both species were performed using MAKER (Cantarel et al. 2008) trained with gene calls from other Phytophthora genomes, including P. ramorum, P. sojae, and P. infestans (Haas et al.

\footnotetext{
†Corresponding author: N. J. Grünwald; E-mail: nik.grunwald@ars.usda.gov
}

Accepted for publication 4 July 2017.
Funding

This work was supported by funds from the United States Department of Agriculture (USDA) Agricultural Research Service Current Research Information System projects 207212220-004-00-D and 2072-22000$039-00-D$ and the USDA National Institute of Food and Agriculture Risk Avoidance and Mitigation Program project 2010-511001-21649.

\section{Keywords} genome, Phytophthora, raspberry, strawberry
This article is in the public domain and not copyrightable. It may be freely reprinted with customary crediting of the source. The American Phytopathological Society, 2017. 
Table 1. Summary statistics of the genome assemblies of Phytophthora fragariae and P. rubi ${ }^{\mathrm{a}}$

\begin{tabular}{lccccccccc} 
Species & $\begin{array}{c}\text { No. } \\
\text { supercontigs }\end{array}$ & $\begin{array}{c}\text { No. } \\
\text { contigs }\end{array}$ & $\begin{array}{c}\text { Total } \\
\text { length (bp) }\end{array}$ & $\begin{array}{c}\text { Genome } \\
\text { coverage }\end{array}$ & N50 (bp) & N90 (bp) & Max (bp) & Min (bp) & $\begin{array}{c}\text { GC } \\
\text { content (\%) }\end{array}$ \\
\hline P. fragariae & 8,511 & 10,440 & $76,752,825$ & $76 \times$ & 18,978 & 3,110 & 258,010 & 200 & 53.35 \\
P. rubi & 9,434 & 11,232 & $74,656,193$ & $92 \times$ & 16,735 & 2,697 & 139,498 & 200 & 53.42 \\
\hline
\end{tabular}

a $\mathrm{N} 50=$ median length of more than $50 \%$ of the supercontigs in the entire assembly; N90 = median length of more than $90 \%$ of the supercontigs in the entire assembly; Max and Min = maximum and minimum lengths, respectively, of supercontigs found in the entire assembly; GC content = percentage of guanine-cytosine bases in the entire assembly.

2009; Tyler et al. 2006). The assembled transcripts were used as RNA evidence in MAKER to improve the quality of the called gene models. The predicted gene models were annotated using InterproScan 5 (Jones et al. 2014).

A total of $6,733 \mathrm{Mbp}$ and $8,382 \mathrm{Mbp}$ raw sequence data were obtained for $P$. fragariae and $P$. rubi, respectively. A low percentage of reads included adapter sequences $(0.02 \%$ for $P$. fragariae, $0.01 \%$ for $P$. rubi) or duplicate reads ( $2 \%$ for $P$. fragariae, $6 \%$ for $P$. rubi). Up to 12 and $16 \%$ of the reads were filtered on the per position quality reported in the FASTQ files for $P$. fragariae and $P$. rubi, respectively, resulting in a total of 5,880 Mbp of clean nucleotides for $P$. fragariae and $6,960 \mathrm{Mbp}$ of clean nucleotides for $P$. rubi.The $P$. fragariae assembly was estimated to be approximately $76 \mathrm{Mbp}$ in size, assembled into 8,511 scaffolds with an N50 of $18,987 \mathrm{bp}$ and a genome sequence depth of $76 \times$ (Table 1). The $P$. rubi genome was assembled into 9,434 scaffolds spanning a total length of $74 \mathrm{Mbp}$ and a N50 of 16,735 bp and a genome sequence depth of $92 \times$ (Table 1). The $P$. rubi genome was assembled into 9,434 scaffolds spanning a total length of approximately $74 \mathrm{Mbp}$ and a N50 of 16,735 bp and a genome coverage of $92 \times$ (Table 1). A total of 20,448 and 23,476 gene models were found for $P$. fragariae and $P$. rubi, respectively. Both species show a high abundance of Gene Ontology terms for DNA integration, nucleic acid binding, protein binding, peptidase/helicase and hydrolase activities, integrases, endonucleases, repeats, and transporter domains.

The genomes of $P$. fragariae and $P$. rubi will provide a unique resource for these closely related soil-borne oomycete plant pathogens and the molecular mechanisms associated with plant pathogenicity.

This Whole Genome Shotgun project has been deposited at GenBank under the accession numbers MWJK00000000 ( $P$. fragariae) and MWJL00000000 ( $P$. rubi). The complete data set used in this report, including the lllumina raw reads and whole genome sequence assembly have been deposited as a National Center for Biotechnology Information BioProject under the accession number PRJNA375089.

\section{Acknowledgments}

We thank D. Shen, B. J. Knaus, and J. Stewart for their support with advice and preliminary data. We also thank the Beijing Genomics Institute (BGI) for conducting the sequencing and assembly. Mention of trade names or commercial products in this manuscript are solely for the purpose of providing specific information and do not imply recommendation or endorsement.

\section{Literature Cited}

Cantarel, B. L., Korf, I., Robb, S. M. C., Parra, G., Ross, E., Moore, B., Holt, C., Sánchez Alvarado, A., and Yandell, M. 2008. MAKER: An easy-to-use annotation pipeline designed for emerging model organism genomes. Genome Res. 18:188-196.

Erwin, D. C., and Ribeiro, O. K. 1996. Phytophthora diseases worldwide. American Phytopathological Society Press, St Paul, MN, U.S.A.

Grabherr, M. G., Haas, B. J., Yassour, M., Levin, J. Z., Thompson, D. A., Amit, I., Adiconis, X., Fan, L., Raychowdhury, R., Zeng, Q., Chen, Z., Mauceli, E., Hacohen, N., Gnirke, A., Rhind, N., di Palma, F., Birren, B. W., Nusbaum, C., Lindblad-Toh, K., Friedman, N., and Regev, A. 2011. Full-length transcriptome assembly from RNASeq data without a reference genome. Nat. Biotechnol. 29:644-652.

Haas, B. J., Kamoun, S., Zody, M. C., Jiang, R. H., Handsaker, R. E., Cano, L. M., Grabherr, M., Kodira, C. D., Raffaele, S., Torto-Alalibo, T., Bozkurt, T. O., Ah-Fong, A. M., Alvarado, L., Anderson, V. L., Armstrong, M. R., Avrova, A., Baxter, L.,
Beynon, J., Boevink, P. C., Bollmann, S. R., Bos, J. I., Bulone, V., Cai, G., Cakir, C., Carrington, J. C., Chawner, M., Conti, L., Costanzo, S., Ewan, R., Fahlgren, N., Fischbach, M. A., Fugelstad, J., Gilroy, E. M., Gnerre, S., Green, P. J., Grenville-Briggs, L. J., Griffith, J., Grünwald, N. J., Horn, K., Horner, N. R., Hu, C. H., Huitema, E., Jeong, D. H., Jones, A. M., Jones, J. D., Jones, R. W., Karlsson, E. K., Kunjeti, S. G., Lamour, K., Liu, Z., Ma, L., Maclean, D., Chibucos, M. C., McDonald, H., McWalters, J., Meijer, H. J., Morgan, W., Morris, P. F., Munro, C. A., O'Neill, K., Ospina-Giraldo, M., Pinzón, A., Pritchard, L., Ramsahoye, B., Ren, Q., Restrepo, S., Roy, S., Sadanandom, A., Savidor, A., Schornack, S., Schwartz, D. C., Schumann, U. D., Schwessinger, B., Seyer, L., Sharpe, T., Silvar, C., Song, J., Studholme, D. J., Sykes, S., Thines, M., van de Vondervoort, P. J., Phuntumart, V., Wawra, S., Weide, R., Win, J., Young, C., Zhou, S., Fry, W., Meyers, B. C., van West, P., Ristaino, J., Govers, F., Birch, P. R., Whisson, S. C., Judelson, H. S., and Nusbaum, C. 2009. Genome sequence 
and analysis of the Irish potato famine pathogen Phytophthora infestans. Nature 461:393-398.

Haas, B. J., Papanicolaou, A., Yassour, M., Grabherr, M., Blood, P. D., Bowden, J., Couger, M. B., Eccles, D., Li, B., Lieber, M., Macmanes, M. D., Ott, M., Orvis, J., Pochet, N., Strozzi, F., Weeks, N., Westerman, R., William, T., Dewey, C. N., Henschel, R., Leduc, R. D., Friedman, N., and Regev, A. 2013. De novo transcript sequence reconstruction from RNA-seq using the Trinity platform for reference generation and analysis. Nat. Protoc. 8:1494-1512.

Jones, P., Binns, D., Chang, H.-Y., Fraser, M., Li, W., McAnulla, C., McWilliam, H., Maslen, J., Mitchell, A., Nuka, G., Pesseat, S., Quinn, A. F., Sangrador-Vegas, A., Scheremetjew, M., Yong, S.-Y., Lopez, R., and Hunter, S. 2014. InterProScan 5: Genome-scale protein function classification. Bioinformatics 30:1236-1240.

Kamoun, S., Furzer, O., Jones, J. D. G., Judelson, H. S., Ali, G. S., Dalio, R. J. D., Roy, S. G., Schena, L., Zambounis, A., Panabières, F., Cahill, D., Ruocco, M., Figueiredo, A., Chen, X.-R., Hulvey, J., Stam, R., Lamour, K., Gijzen, M., Tyler, B. M., Grünwald, N. J., Mukhtar, M. S., Tomé, D. F. A., Tör, M., Van Den Ackerveken, G., McDowell, J., Daayf, F., Fry, W. E., Lindqvist-Kreuze, H., Meijer, H. J. G., Petre, B., Ristaino, J., Yoshida, K., Birch, P. R. J., and Govers, F. 2015. The top 10 oomycete pathogens in molecular plant pathology. Mol. Plant Pathol. 16:413-434.
Luo, R., Liu, B., Xie, Y., Li, Z., Huang, W., Yuan, J., He, G., Chen, Y., Pan, Q., Liu, Y., Tang, J., Wu, G., Zhang, H., Shi, Y., Liu, Y., Yu, C., Wang, B., Lu, Y., Han, C., Cheung, D. W., Yiu, S.-M., Peng, S., Xiaogian, Z., Liu, G., Liao, X., Li, Y., Yang, H., Wang, J., Lam, T.-W., and Wang, J. 2012. SOAPdenovo2: An empirically improved memory-efficient short-read de novo assembler. Gigascience 1:18.

Stewart, J. E., Kroese, D., Tabima, J. F., Larsen, M. M., Fieland, V. J., Press, C. M., Zasada, I. A., and Grünwald, N. J. 2014. Pathogenicity fungicide resistance and genetic variability of Phytophthora rubi isolates from raspberry (Rubus idaeus) in the western United States. Plant Dis. 98:1702-1708.

Tyler, B. M., Tripathy, S., Zhang, X., Dehal, P., Jiang, R. H., Aerts, A., Arredondo, F. D., Baxter, L., Bensasson, D., Beynon, J. L., Chapman, J., Damasceno, C. M., Dorrance, A. E., Dou, D., Dickerman, A. W., Dubchak, I. L., Garbelotto, M., Gijzen, M., Gordon, S. G., Govers, F., Grünwald, N. J., Huang, W., Ivors, K. L., Jones, R. W., Kamoun, S., Krampis, K., Lamour, K. H., Lee, M. K., McDonald, W. H., Medina, M., Meijer, H. J., Nordberg, E. K., Maclean, D. J., Ospina-Giraldo, M. D., Morris, P. F., Phuntumart, V., Putnam, N. H., Rash, S., Rose, J. K., Sakihama, Y., Salamov, A. A., Savidor, A., Scheuring, C. F., Smith, B. M., Sobral, B. W., Terry, A., Torto-Alalibo, T. A., Win, J., Xu, Z., Zhang, H., Grigoriev, I. V., Rokhsar, D. S., and Boore, J. L. 2006. Phytophthora genome sequences uncover evolutionary origins and mechanisms of pathogenesis. Science 313:1261-1266. 